\title{
The effect of digital marketing and e-commerce on financial performance and business sustaina- bility of MSMEs during COVID-19 pandemic in Indonesia
}

\author{
Mas Intan Purba $^{a^{*}}$, Demak Claudia Yosephine Simanjutak ${ }^{\mathrm{b}}$, Yois Nelsari Malau ${ }^{\mathrm{b}}$, Walmi Sholihat ${ }^{\mathrm{c}}$ and \\ Edy Anas Ahmadi ${ }^{\text {d }}$
}

aLecturer, Universitas Prima Indonesia, Indonesia

${ }^{b}$ Lecturer, Universitas Prima Indonesia, Indonesia

${ }^{c}$ Lecturer, Sekolah Tinggi Ilmu Ekonomi Indragiri (STIE-I) Rengat, Indonesia

${ }^{d}$ Lecturer, Sekolah Tinggi Ekonomi Islam Permata Bojonegoro, Indonesia

\section{H R O N I C L E}

Article history:

Received: March 11, 2021

Received in revised format: April

9, 2021

Accepted: May 30, 2021

Available online: June 7, 2021

Keywords:

Digital Marketing

E-Commerce

Business Sustainability

Financial Performance

MSMES

\section{A B S T R A C T}

\begin{abstract}
The purpose of this study is to analyze the effects of digital marketing (DM), e-commerce (EC), business sustainability (BS) and financial performance (FP) of Micro, Small and Medium Enterprises (MSMEs) during Pandemic Covid19 in Indonesia. The relationships between digital marketing and business sustainability, e-commerce and business sustainability, digital marketing and financial performance, e-commerce and financial performance, financial performance and business sustainability are investigated. This research is quantitative research with a questionnaire approach. Data processing tools use the SmartPLS 3.3.3 software. The primary data collection method was accomplished by distributing online questionnaires to 120 MSMEs in Banten Indonesia who had experienced the pandemic. The results show that digital marketing had significant effect on business sustainability, e-commerce had significant effect on business sustainability, digital marketing had significant effect on financial performance. However, e-commerce had no significant effect on financial performance, financial performance had no significant effect on business sustainability, digital marketing had no significant effect on business sustainability through financial performance, e-commerce had no significant effect on business sustainability through financial performance. The use of digital marketing has been carried out to increase customer awareness. Marketplace as a manifestation of e-commerce is used as an innovation or change in sales methods.
\end{abstract}

(C) 2021 by the authors; licensee Growing Science, Canada.

\section{Introduction}

MSMEs is a form of micro and medium scale business and growing rapidly in Indonesia with an absorption rate of $97.2 \%$ of the workforce in Indonesia. The same thing was expressed that the employment of college graduates is still low, around 7.2\% of the workforce and some of these graduates eventually turned into entrepreneurs. It cannot be denied that MSMEs have a central role in the national economy. Aggarwal et al. (2021) reveal that MSMEs Indonesia still suffers from a low productivity domain and revealed that the most important factor of MSME performance is the human resources itself. In line with research Alzaam et al. (2021) reported that productive entrepreneurship of MSMEs contributes to economic growth. The indicators used are institutional quality, financial performance, local government, and the ability to start a business. COVID-19 has changed behavior, business strategy. According to Amri et al. (2021), businesspeople are forced to change completely. The business has undergone a complete reset. Marketing, management, and business theories that were used in earlier eras were almost invalid during a pandemic. So, the business experiences a new normal phase, where everything that is done by businesspeople and consumers is completely new. This is none other than responding to the new normal period during the post-

* Corresponding author.

E-mail address: masintanpurba84@gmail.com (M. I. Purba)

(C) 2021 by the authors; licensee Growing Science, Canada. doi: $10.5267 /$ j.ijdns.2021.6.006 
pandemic. Consumers as direct partners in a business transaction also experience changes. Consumers are more focused on value. Marketing activities, especially during a pandemic, can create economic value. This economic value can determine the price of a product. Apart from focusing on value, consumers will also rebuild awareness. During the pandemic, consumers have almost forgotten the brand, so communication through digital advertising will increase brand awareness again. Even this digital behavior encourages the expansion of online consumers no longer to the millennial generation. The Covid19 pandemic has changed the behavior of both consumers and producers. This change in behavior cannot be separated from the rules during the pandemic which force individuals to carry out physical distancing. Everyone is reluctant to go out, crowd, and even their activities are restricted. All these limitations in the end also have a serious impact on businesspeople. Social interactions have become almost interrupted during the pandemic. Social interaction is limited to bulkheads and virtual world spaces. The market crowd where consumers interact with businesspeople directly has suspended animation. Another impact experienced by MSME actors is quite serious. Asbari et al. (2021) state that only 5.9\% of MSMEs can benefit during a pandemic. The remaining $82.9 \%$ are negatively affected. Some UMKM players have experienced a decrease in their turnover. Of the 37 thousand MSMEs that were recorded, $63.9 \%$ experienced a decline in turnover of $>30 \%$. Meanwhile, another $31.7 \%$ experienced a decrease in turnover of between $0-30 \%$.

This situation shows that the business world is in bad shape. Micro, Small and Medium Enterprises (MSMEs) are the most affected parties. Thousands of MSME actors have reported being very seriously affected by this pandemic. Their business is reported to have decreased by up to $56 \%$. The research conducted by Affandi et al. (2020) revealed that in addition to decreasing income, these MSME actors also experienced difficulties in financing, distribution, and obtaining raw materials. This condition cannot be separated from the uncertainty during the pandemic. Research reveals a decrease in the capital of MSMEs by up to $60 \%$ due to this chronic pandemic. This extreme uncertainty has an impact on the source of funding for entrepreneurs. This uncertainty causes the growth of MSMEs to slow down, even go bankrupt. But not a few of them finally got up and recovered to face the pandemic. These recovering MSMEs are those who can adapt to the conditions of the pandemic, then make designs and implement new strategies in doing business. This research will examine and make studies related to the sustainability of the MSME and E-Commerce business as a marketplace tool supported by digital marketing. Digital marketing is an effort to market a product. The use of technology in every process is a hallmark of digital marketing. This has proven to be able to increase the selling power of products, especially from MSMEs. E-commerce can be defined as a process of buying or selling products electronically carried out by consumers to companies or consumers to consumers with the help of computer and internet equipment. A literature study conducted by Budi et al. (2020) reveals that the variety of products that can be sold in the marketplace is an initial capital for opportunities for large market share. One of the keys to being the biggest marketplace is in terms of service and sales transaction guarantees. This is in line with what has been stated Bernarto et al. (2020); Fahmi et al. (2020); Hartono and Maksum (2020) that the services provided by the marketplace are able to increase consumer confidence in using them. Meanwhile Ismaya et al. (2020); Leu and Masri (2021); Muafi et al. (2021) and Naushad (2021) addressing the use of marketplaces as a means of buying and selling is a manifestation or implementation of the 4.0 industrial revolution. Digital marketing used in this case is social media. Of the 50\% of MSME business actors who were able to rise, almost all of them have adapted to digital strategies. This change concerns sales procedures, promotions, distribution, supply chains, and others. If in normal times businesspeople can do it offline, then this cannot be done again during a pandemic. The purpose of this study is to analyze the influence of digital marketing (DM), e-commerce (EC), business sustainability (BS) and financial performance (FP) of e-commerce companies during Pandemic Covid19 in Indonesia. The relationship digital marketing and business sustainability, The relationship e-commerce and business sustainability, The relationship digital marketing and financial performance, The relationship e-commerce and financial performance, The relationship financial performance and business sustainability.

\section{Research model}

This research is quantitative research with a questionnaire approach. Data processing tools use the SmartPLS 3.3.3 software. The primary data collection method was by distributing online questionnaires to 120 MSMEs in Banten Indonesia who had experienced the pandemic. According to Purwanto et al. (2021); Pham et al. (2021); Quddus et al. (2020) and Rahaman et al. (2021), in the PLS (Partial Least Square) method the analysis technique is the analysis of the outer model is carried out to ensure that the measurement used is appropriate to be measured (valid and reliable). In this model analysis, it specifies the relationship between latent variables and their indicators. Analysis of the outer model can be seen from several indicators. Convergent Validity is an indicator that is judged based on the correlation between the item score / component score with the construct score, which can be seen from the standardized loading factor which describes the magnitude of the correlation between each measurement item (indicator) and its construct. The individual reflexive size is said to be high if it correlates> 0.7 with the construct you want to measure, the outer loading value between $0.5-0.6$ is considered sufficient. Discriminant Validity is a measurement model with reflexive indicators that were assessed based on cross loading measurements with constructs. If the construct correlates with the measurement item is larger than the size of the other constructs, it shows their block size is better compared to other blocks. Meanwhile, according to other methods to assess discriminant validity namely by comparing the value of the square root of average variance extracted (AVE). Composite reliability is an indicator to measure a construct that can be seen in the latent variable coefficients view. According to Alzaam et al. (2021); Amri et al. (2021) and Asbari et al. (2021), to evaluate composite reliability, there are two measuring tools namely internal consistency and Cronbach's alpha. In measurement if the value achieved is $>0.70$ then it can be said that the construct has high reliability. 
Cronbach's Alpha is a reliability test that was conducted to strengthen the results of composite reliability. A variable can be declared reliable if it has a Cronbach's alpha value> 0.7. According to Yunarsih et al. (2020); Wanasida et al. (2021); Alzaam et al. (2021); Amri et al. (2021) and Asbari et al. (2021), Inner model analysis is usually also called (interrelation, structural model, and substantive theory) which one describe the relationship between latent variables based on substantive theory. Inner model analysis can be evaluated by using the R-square for the dependent construct, the Stone-Geisser Q-Square test for predictive relevance and the $t$ test as well as the significance of the structural path parameter coefficients. In evaluating the inner model with PLS (Partial Least Square), it is started by looking at the R-Squared for each dependent latent variable. Then the interpretation is the same as the interpretation in regression. Changes in the value of the R-square can be used to assess the effect of certain independent latent variables on the dependent latent variables whether they have a substantive effect. Apart from seeing the R-square value, at The PLS (Partial Least Square) model was also evaluated by looking at the predictive Qsquare value of relevance for the constructive model. Q-square measures how well the observed value is generated by the model and estimated parameters. Q-square value greater than 0 (zero) shows that the model has predictive relevance value, whereas if the Q-square value is less than 0 (zero), then shows that the model lacks predictive relevance. In testing the hypothesis, it can be seen from the t-statistical value and probability value. According to Nugroho et al. (2020); Nguyen et al. (2021); Pramono et al. (2021); Adha et al. (2020) and Praditya (2020), to test the hypothesis, namely by using statistical values, for alpha 5\% the t-statistic value used is 1.96 and the criteria for acceptance / rejection of the hypothesis is Ha accepted and $\mathrm{H}_{0}$ is rejected when the t-statistic is $>1.96$. For rejecting / accepting the hypothesis using probability, then Ha is accepted if the $\mathrm{p}$ value is $<0.05 .2$. Based on the problems and previous research, the following hypotheses were obtained:

$\mathbf{H}_{1}$ : Digital marketing (DM) has a positive effect on business sustainability (BS).

$\mathbf{H}_{2}$ : e-commerce (EC) has a positive effect on business sustainability (BS).

$\mathbf{H}_{3}$ : Digital marketing (DM) has a positive effect on financial performance (FP),

$\mathbf{H}_{4}$ : e-commerce (EC) has a positive effect on financial performance (FP).

H5: Financial performance (FP) has a positive effect on business sustainability (BS).

$\mathbf{H}_{6}$ : Digital marketing (DM), have a positive effect on business sustainability (BS) through financial performance (FP).

$\mathbf{H}_{7}$ : e-commerce (EC) has a positive effect on business sustainability (BS) through financial performance (FP).

Fig. 1 demonstrates the structure of the proposed study of this paper.

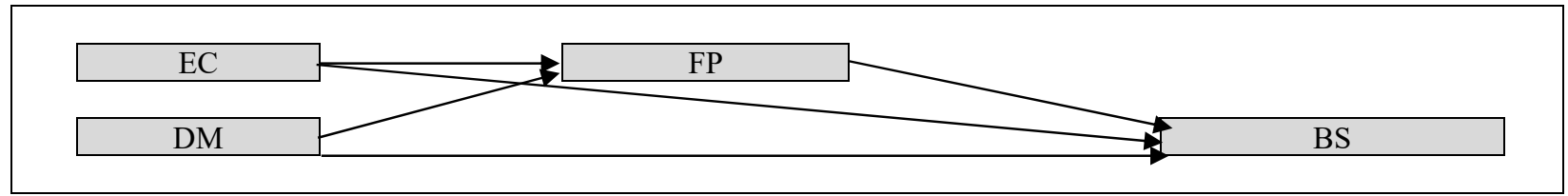

Digital marketing (DM), e-commerce (EC), Business Sustainability (BS) and Financial Performance E-Commerce Company During Pandemic Covid19 in Indonesia (FP)

Fig. 1. The proposed study

\section{Results and discussion}

\subsection{Test Results of the Validity and Reliability of Research Indicators}

The testing phase of the measurement model includes testing for convergent validity, discriminant validity and composite reliability. The results of the PLS analysis can be used to test the research hypothesis if all indicators in the PLS model have met the requirements of convergent validity, discriminant validity and reliability testing. Convergent validity test is done by looking at the loading factor value of each indicator against the construct (Fig. 2). In most references, a factor weight of 0.5 or more is considered to have sufficiently strong validation to explain latent constructs (Purwanto, 2021). In this study, the minimum limit for the accepted loading factor is 0.5 , provided that the AVE value of each construct is $>0.5$ (Asbari, 2021).

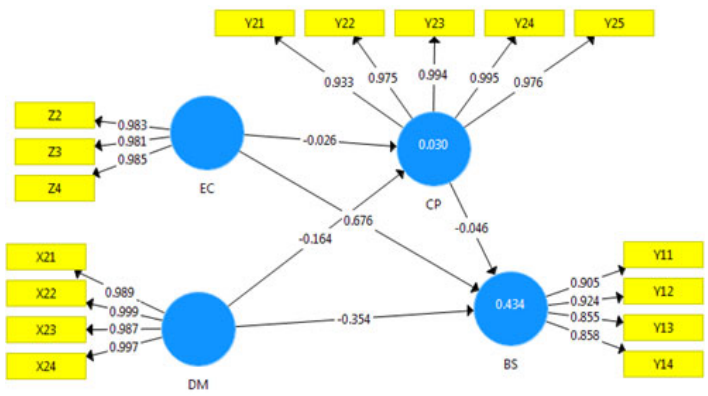

Fig. 2. Convergent Validity Testing 
Based on the estimation results of the PLS model in the image above, all indicators have a loading factor value above 0.5 so that the model has met the convergent validity requirements. Apart from looking at the loading factor value of each indicator, convergent validity was also assessed from the AVE value of each construct. The AVE value for each construct of this study is more than 0.5 . So, the convergent validity of this research model has met the requirements. The value of loadings, Cronbach's alpha, composite reliability, and AVE for each complete construct can be seen in Table 1:

Table 1

Cronbach's Alpha, Composite Reliability, and Average Variance Extracted (AVE)

\begin{tabular}{cccc}
\hline & Cronbach's Alpha & rho_A & Composite Reliability \\
\hline BS & 0,91 & 0,927 & 0,936 \\
CP & 0,987 & 1,016 & 0,99 \\
DM & 0,995 & 0,998 & 0,785 \\
EC & 0,982 & 0,984 & 0,950 \\
0
\end{tabular}

\subsection{Construction Reliability Testing}

Construct reliability can be assessed from the Cronbach's alpha value and the composite reliability of each construct. The recommended composite reliability and Cronbach's alpha value is more than 0.7 (Asbari, 2020). The results of the reliability test in Table 1 above show that all constructs have composite reliability and Cronbach's alpha values are greater than 0.7 ( $>$ 0.7). In conclusion, all constructs have met the required reliability. Discriminant validity is done to ensure that each concept of each latent variable is different from other latent variables. The model has good discriminant validity if the AVE square value of each exogenous construct (the value on the diagonal) exceeds the correlation between this construct and other constructs (values below the diagonal). The results of the discriminant validity test show that all constructs have a square root value of AVE and the correlation value with other latent constructs (through the Fornell-Larcker criteria) so that it can be concluded that the model has met discriminant validity. The effect test was performed using the t-statistic test in the partial least squared (PLS) analysis model using the SmartPLS 3.0 software. With the bootstrapping technique, the R Square value and the significance test value are obtained as shown in Table 2:

Table 2

The results of R-Square values

\begin{tabular}{lll}
\hline & R Square & R Square Adjusted \\
\hline BS & 0.434 & 0.427 \\
FP & 0.030 & 0.022 \\
\hline
\end{tabular}

Based on Table 2, the R Square value for business sustainability (BS) is 0.434 , which means that business sustainability (BS) variable can be explained by digital marketing (DM), e-commerce (EC), and financial performance (FP) $43.3 \%$, the value of $\mathrm{R}$ Square for financial performance (FP) is 0.030 , which means that the financial performance (FP) variable can be explained by digital marketing (DM), e-commerce (EC) variable by $3 \%$.

\subsection{Hypothesis testing}

Hypothesis testing in PLS is also known as the inner model test. This test includes a significance test for direct and indirect effects as well as a measurement of the magnitude of the influence of exogenous variables on endogenous variables. The results of hypothesis testing for all variables that have a direct effect are shown in Fig. 3 and Table 3.

Table 3

The results of testing direct effects

\begin{tabular}{lccl}
\hline Hypothesis & $\begin{array}{c}\text { Standardized } \\
\text { Path Coefficient } \\
(\boldsymbol{\beta})\end{array}$ & t-value & Test Result \\
\hline $\mathbf{H}_{\mathbf{1}}: \mathrm{AT} \leftarrow \mathrm{EE}$ & 0.635 & $7.706^{* *}$ & \\
\hline $\mathbf{H}_{2}: \mathrm{AT} \leftarrow \mathrm{PE}$ & 0.190 & $3.601^{* *}$ & Supported \\
$\mathbf{H}_{3}: \mathrm{AT} \leftarrow \mathrm{SI}$ & 0.204 & $3.285^{* *}$ & Supported \\
$\mathbf{H}_{4}: \mathrm{DE} \leftarrow \mathrm{AT}$ & 0.993 & $14.534^{* *}$ & Supported \\
$\mathbf{H}_{5}: \mathrm{BI} \leftarrow \mathrm{DE}$ & 0.155 & $2.540^{* *}$ & Supported \\
$\mathbf{H}_{6}: \mathrm{BI} \leftarrow \mathrm{PI}$ & 0.540 & $7.550^{* *}$ & Supported \\
$\mathbf{H}_{7}: \mathrm{BI} \leftarrow \mathrm{SI}$ & 0.252 & $3.669^{* *}$ & Supported \\
\hline
\end{tabular}

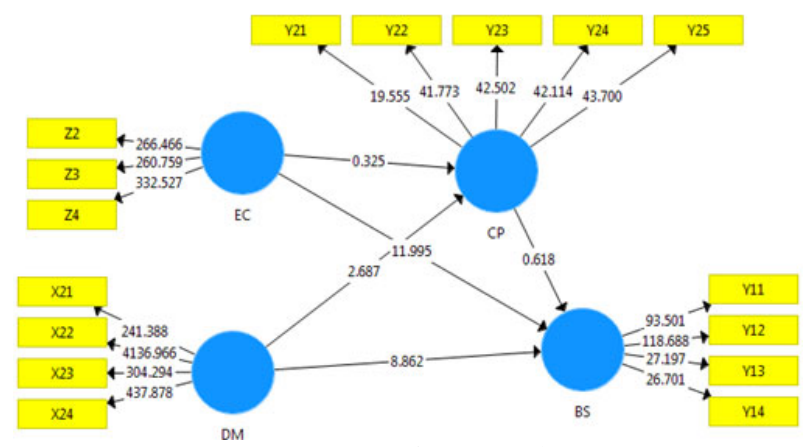

Fig. 3. Hypotheses testing

H1: Digital marketing (DM) has a positive effect on business sustainability (BS).

Based on regression test results, the result of the $p$ value is significant $p$ value is $0.000<0.050$, which means digital marketing (DM), has significant effect on business sustainability (BS). This means that an increase in digital marketing (DM), will 
encourage business sustainability (BS) and a decrease in digital marketing (DM), will encourage a decrease in business sustainability (BS). The results of this study are aligned with Nugroho et al. (2020); Nguyen et al. (2021); Pramono et al. (2021); Adha et al. (2020) and Praditya (2020) who state that digital marketing (DM) has significant effect on business sustainability (BS).

$\mathbf{H}_{2}$ : e-commerce (EC) has a positive effect on business sustainability (BS).

Based on regression test results, the result of the $\mathrm{p}$ value has a significant $\mathrm{p}$ value which is $0.000<0.050$, which means ecommerce (EC) has a significant effect on business sustainability (BS). This means that an increase in e-commerce (EC) will encourage business sustainability (BS). and a decrease in e-commerce (EC) will encourage a decrease in business sustainability (BS). The results of this study are aligned with Priadana et al. (2021); Purwanto et al. (2021); Pham et al. (2021); Quddus et al. (2020) and Rahaman et al. (2021) who state that e-commerce (EC) has significant effect on business sustainability (BS).

\section{H3: Digital marketing (DM) has a positive effect on financial performance (FP).}

Based on regression test results shows the result of the $\mathrm{p}$ value is significant $\mathrm{p}$ value is $0.007<0.050$, which means Digital marketing (DM) has significant effect on financial performance (FP)This means that an increase in Digital marketing (DM) will encourage financial performance (FP)and a decrease in Digital marketing (DM) will encourage a decrease in financial performance (FP). The results of this study are aligned with Singhdong et al. (2021); Suheny et al. (2020); Syafri et al. (2021); Tan et al. (2021) and Tran and Truong (2021) who state that Digital marketing (DM) has significant effect on financial performance (FP).

\section{H4: e-commerce (EC) has a positive effect on financial performance (FP).}

The regression test results show the $\mathrm{p}$ value does not yield a significant $\mathrm{p}$ value (i.e. $0.746>0.050$ ), which means e-commerce (EC) has no significant effect on financial performance (FP). This means that an increase in e-commerce (EC) will not encourage financial performance (FP) and a decrease in e-commerce ( EC) will not encourage a decrease in financial performance (FP). The results of this study are aligned with Yunarsih et al. (2020); Wanasida et al. (2021); Alzaam et al . (2021); Amri et al. (2021) and Asbari et al. (2021) who state that e-commerce (EC) has no significant effect on financial performance (FP).

\section{H5: Financial performance (FP) has a positive effect on business sustainability (BS).}

Based on regression test results, the $p$-value has a significant $p$ value of $0.537<0.050$, which means financial performance (FP) has no significant effect on business sustainability (BS). This means that an increase in financial performance (FP) will not encourage business sustainability (BS) and a decrease in financial performance (FP) will not encourage a decrease in business sustainability (BS). The results of this study are aligned with Priadana et al. (2021); Purwanto et al. (2021); Pham et al. (2021); Quddus et al. (2020) and Rahaman et al. (2021) who state that financial performance (FP) has no significant effect on business sustainability (BS).

\section{H6: Digital marketing (DM), has a positive effect on business sustainability (BS) through financial performance (FP).}

Based on regression test results, the result of the $p$ value yields a significant $p$ value of $0.573>0.050$, which means digital marketing (DM), has no significant effect on business sustainability (BS) through financial performance (FP). This means that an increase in digital marketing (DM) will not encourage business sustainability (BS) through financial performance (FP) and a decrease in digital marketing (DM) will not encourage a decrease in business sustainability (BS) through financial performance (FP). The results of this study are aligned with Asbari et al. (2021), Astuti et al. (2020) and Basri et al. (2020) who state that digital marketing (DM) has no significant effect on business sustainability (BS) through financial performance (FP).

\section{H7: e-commerce (EC) has a positive effect on business sustainability (BS) through financial performance (FP).}

Based on regression test results, the result of the $p$ value is not significant since the $p$ value is $0.859>0.050$, which means ecommerce (EC) has no significant effect on business sustainability (BS) through financial performance (FP). This means that an increase in e-commerce (EC) will not encourage business sustainability (BS) through financial performance (FP) and a decrease in e-commerce (EC) will not encourage a decrease in business sustainability (BS) through financial performance (FP). The results of this study are aligned with Affandi et al. (2020); Budi et al. (2020); Bernarto et al. (2020); Fahmi et al. (2020); Hartono and Maksum (2020) who state that e-commerce (EC) has no significant effect on business sustainability (BS) through financial performance (FP). 


\subsection{Discussion}

Research conducted by Ismaya et al. (2020); Leu and Masri (2021); Muafi et al. (2021) and Naushad (2021) have revealed that the use of social media was able to boost sales of handicraft products for PKK mothers. Digital marketing by utilizing WhatsApp (WA), Instagram (IG), Facebook (FB) and other social media facilities can significantly increase revenue. The media makes it easier for them to market the products they produce. Research conducted by Alzaam et al. (2021); Amri et al. (2021) and Asbari et al (2021) have revealed that digital marketing management has an impact on increasing start-up business revenue. But what is often the problem is that they do not understand how to make good content. In addition, there is very little response to the content provided. This is inseparable from the literacy of MSME actors towards the digital world itself. The same thing was also expressed (Susilo, 2018) where in his research revealed that there were differences in the profile of a demographic of social media users. So, a digital marketing communication strategy is needed so that it would not go wrong. The pandemic period hit the MSME sector badly. Few of the businesses were able to survive. Apart from business competition, it is also necessary to develop its business by creating a competitive advantage over its competitors. Apart from surviving with a competitive advantage, product marketing strategies must also get attention by carrying out various strategies, the sustainability of these micro and medium enterprises will be able to survive the pandemic. Some MSMEs can survive during a pandemic, apart from changing the way they run their business from conventional to digital, there are other strategies being implemented. This strategy is related to operations and production processes. According to Purwanto et al. (2021); Pham et al. (2021); Quddus et al. (2020) and Rahaman et al. (2021) MSME actors reduce their production process. However, not a few have added production. This reduction in the production process is related to consumer behavior that tends to lie down in the face of a pandemic. MSME players have made various attempts to boost their business. Other strategies undertaken by MSME players are related to financial or financial management. Several MSMe players applied for credit to increase business capital.

MSMEs that can survive a pandemic are those who are able to find ways to survive. One of the ways MSMEs survive is to add types of expansion channels in sales and marketing. The expansion of alternative channels of selling and marketing is related to the use of the internet media (marketplace). Several reasons MSMEs use the internet to run their business for various reasons. One of the reasons for using internet media in running its business is marketing products through social media. Marketing of MSME products / services through social media has become a trend and a necessity during difficult times. The use of social media as a tool to market their goods / services was $60.2 \%$. However, the transformation of these changes is not without obstacles. Some UMKM players who are still reluctant to use digital means admit that they are not able to use the internet properly. Apart from that, there are their limitations in terms of infrastructure which are still inadequate / inadequate regarding access to internal services.

The results of this study can be used by MSME actors to make decisions in the uncertainty of a pandemic. This research can also provide recommendations for further research or development for other researchers. Further research is meant to develop a business strategy using anomalous indicators. This study is slightly different from previous similar studies. Previous research by Syafri et al. (2021); Tan et al. (2021) and Tran and Truong (2021) examined the business sustainability of MSMEs under normal conditions and competition between MSME businesses. However, during the COVID19 pandemic, conditions were much different. This is inseparable from the condition of the market anomaly that permeates MSME products. MSMEs are facing the most difficult times in their business history. The difficulty is not only fighting against business competition between MSMEs, but also fighting against uncertain market conditions during the COVID19 period. This research describes a change in the behavior of both MSME actors and buyers in the face of a pandemic. This research also shows that the surviving MSMEs are those who can adapt and innovate their services and production processes.

\section{Conclusion}

The data analysis has shown that digital marketing has significant effect on business sustainability, e-commerce has significant effect on business sustainability, digital marketing has significant effect on financial performance, e-commerce has no significant effect on financial performance, financial performance has no significant effect on business sustainability, digital marketing has no significant effect on business sustainability. Moreover, financial performance-commerce has no significant effect on business sustainability through financial performance. The pandemic has changed the business order in almost all fields. The uncertainty during the pandemic has resulted in several MSME players having to experience a decrease in income. However, not a few have survived or even increased. Some of the surviving MSMEs are those who have made changes to their business strategies. These changes are related to the way they sell and promote their products. Digital marketing using social media was chosen by MSME players to increase the reach of their product marketing during a pandemic. Meanwhile, the use of e-commerce (marketplace) as a means of selling is one of the strategies to survive by changing the sales model. The reach of the marketplace is much wider than conventional sales models. However, as a new player in the marketplace world, MSME players face new problems in terms of business competition. So, the use of digital marketing that is integrated directly with the marketplace is key in maintaining the continuity of the MSME business during a pandemic. 
The limitation in this study is that it uses secondary data from literature and previous studies. As a result of the development of this research, further research can be carried out which examines MSME actors surviving in anomalous conditions with a qualitative model. This qualitative model examines in depth the MSME actors who can survive a pandemic starting from their business change model.

\section{References}

Adha, S., Sintawati, F., Julyanto, O., Wulandari, R. A., \& Purwanto, A. (2020). Leadership Style For Indonesian Public Health Center: Charismatic, Bureaucratic, Transactional, Transformational, Autocratic Or Democratic?. European Journal of Molecular \& Clinical Medicine, 7(7), 115-124.

Aggarwal, K., Malik, S., Misshra, D. K., \& Paul, D. (2021). Moving from Cash to Cashless Economy: Toward Digital India. The Journal of Asian Finance, Economics and Business, 8(4), 43-54. https://doi.org/10.13106/JAFEB.2021.VOL8.NO4.0043

Alzaam, A. F., \& Almizeed, K. (2021). The Effect of Digital Marketing on Purchasing Decisions: A Case Study in Jordan. The Journal of Asian Finance, Economics and Business, 8(5), 455-463. https://doi.org/10.13106/JAFEB.2021.VOL8.NO5.0455

Amri, W. A. A., Asbari, M., Gazali, G., Novitasari, D., \& Purwanto, A. (2021). The Effect of Religiosity and Service Quality on Job Satisfaction: A Case Study of MSME Employees. International Journal of Social and Management Studies, 2(1), 53-63. https://doi.org/10.5555/ijosmas.v2i1.7

Asbari, M., Dylmoon Hidayat, D., \& Purwanto, A. (2021). Managing Employee Performance: From Leadership to Readiness for Change. International Journal of Social and Management Studies, 2(1), 74-85. https://doi.org/10.5555/ijosmas.v2i1.12

Affandi, A., Sarwani, Sobarna, A., Erlangga, H., Siagian, A. O., Purwanto, A., Effendy, A. A., Sunarsi, D., Wicaksono, W., Suyatin, Ariyanti, E., Wahyitno, Manik, C. D., Juhaeri, \& Gunartin, (2020) Optimization of MSMEs Empowerment in Facing Competition in the Global Market during the COVID-19 Pandemic Time. Systematic Reviews in Pharmacy, 11 (11), 1506-1515. doi:10.31838/srp.2020.11.213

Budi, \& Maksum, I. (2020). The Importance of Changing Management Styles in The Digital Age: The Importance of Changing Management Styles in The Digital Age. Journal of Industrial Engineering \& Management Research, 1(3), 148154. https://doi.org/10.7777/jiemar.v1i3.75

Bernarto, Bachtiar, Sudibjo, Suryawan, Purwanto \& Asbari (2020). Effect of Transformational Leadership, Perceived Organizational Support, Job Satisfaction Toward Life Satisfaction: Evidences from Indonesian Teachers. International Journal of Advanced Science and Technology, 29(3). 5495 -5503

Fahmi, K., Kurniawan, T., Cahyono, Y., Sena, A., Suhadarliyah, Suryani, P., Sugianto, A., Amelia, D., Musnaini, Amin, S., Hasbullah, H., Jihadi, M., Wijoyo, H. \& Purwanto, A. (2020) Did Servant, Digital and Green Leadership Influence Market Performance? Evidence from Indonesian Pharmaceutical Industry. Systematic Reviews in Pharmacy, 11(9), $642-653$. doi:10.31838/srp.2020.9.95

Hartono, B., \& Maksum, I. (2020). The Importance of Changing Management Styles in The Digital Age: The Importance of Changing Management Styles in The Digital Age. Journal of Industrial Engineering \& Management Research, 1(3), 148154. https://doi.org/10.7777/jiemar.v1i3.75

Ismaya, B., Setiawan,T., Sulistyarini, . I., Winarti,A., Nabila, . R., Purnamaningsih, I. R., Haryati, ., Widodo, A. P., Klau, I. C. S. \& Purwanto, A. (2020) FAST Leadership Model for University Leaders Performance in Pharmacy Faculty: Yesterday, Today and Tomorrow. Systematic Reviews in Pharmacy, 11(8), 362-373. doi:10.31838/srp.2020.8.54

Leu, J. F. Y., \& Masri, R. (2021). Omni-Channel Retailing and Digital Business: A Case Study in Malaysia. The Journal of Asian Finance, Economics and Business, 8(4), 403-412. https://doi.org/10.13106/JAFEB.2021.VOL8.NO4.0403

Muafi, M., Syafri, W., Prabowo, H., \& Nur, S. A. (2021). Digital Entrepreneurship in Indonesia: A Human Capital Perspective. The Journal of Asian Finance, Economics and Business, 8(3), 351-359. https://doi.org/10.13106/JAFEB.2021.VOL8.NO3.0351

Naushad, M. (2021). Investigating Determinants of Entrepreneurial Leadership Among SMEs and Their Role in Sustainable Economic Development of Saudi Arabia. The Journal of Asian Finance, Economics and Business, 8(4), $225-237$. https://doi.org/10.13106/JAFEB.2021.VOL8.NO4.0225

Nugroho, B. S., Widdah, M. E., Suryana, A. T., Ibrahim, T., Humaira, M. A., Nasrudin, M., Mubarok, M. S., Abadi, M. T., Adisti, A. R., Gadzalia, S. S., Muqtada, M. R., Purwanto, .A., Fahlevi, M. \& Sudargini, Y. (2020) Effect of Leadership Style Toward Indonesian Education Performance in Education 4.0 Era: A Schematic Literature Review. Systematic Reviews in Pharmacy, 11(10), 371-378. doi:10.31838/srp.2020.10.60

Nguyen, H., Tran, T. H. M., Nguyen. H. Y., \& Truong, D. D. (2021). The Influence of Competitive Advantage on Financial Performance: A Case Study of SMEs in Vietnam. The Journal of Asian Finance, Economics and Business, 8(5), 335-343. https://doi.org/10.13106/JAFEB.2021.VOL8.NO5.0335

Pramono, R., Sondakh, L.W, Bernarto , I., Juliana, \& Purwanto, A.S. (2021) Determinants of the Small and Medium Enterprises Progress: A Case Study of SME Entrepreneurs in Manado, Indonesia. The Journal of Asian Finance, Economics, and Business, 8(1), 881-889. https://doi.org/10.13106/JAFEB.2021.VOL8.NO1.881 
Praditya, R. A. (2020). Leadership, Work Motivation, Competency, Commitment and Culture: Which influences The Performance of Quality Management System in Automotive Industry?. Journal of Industrial Engineering \& Management Research, 1(1), 53-62. https://doi.org/10.7777/jiemar.v1i1.27

Priadana, S., Sunarsi, D., Wahyitno, A. P. S., Mogi, A., Agustin, F., Irawati, L., ... \& Purwanto, A. (2021). The Effect of Strategic Leadership on Competitive Strategy and Business Performance: Evidence from Indonesian SME's. Annals of the Romanian Society for Cell Biology, 4908-4918.

Purwanto, A., Asbari, M., Hartuti, H., Setiana, Y. N., \& Fahmi, K. (2021). Effect of Psychological Capital and Authentic Leadership on Innovation Work Behavior. International Journal of Social and Management Studies, 2(1), 1-13. https://doi.org/10.5555/ijosmas.v2i1.4

Pham Thi, T. D., Ngo, A. T., Duong, N. T., \& Pham, V. K. (2021). The Influence of Organizational Culture on Employees' Satisfaction and Commitment in SMEs: A Case Study in Vietnam. The Journal of Asian Finance, Economics and Business, 8(5), 1031-1038. https://doi.org/10.13106/JAFEB.2021.VOL8.NO5.1031

Quddus, A., Nugroho, B. S., Hakim, L., Ritaudin, . M. S., Nurhasanah, E., Suarsa, . A., Karyanto, U. B., Tanjung, R., Hendar, Pratama, . V. Y., Awali, H., Mufid, A., Purwanto, . A., Fahlevi, M. \& Sudargini, Y. (2020) Effect of Ecological, Servant dan Digital Leadership Style Influence University Performance? Evidence from Indonesian Universities. Systematic Reviews in Pharmacy, 11(10), 408-417. doi:10.31838/srp.2020.10.64

Rahaman, M. A., Luna, K. F., Ping, Z. L., Islam, M. S., \& Karim, M. M. (2021). Do Risk-Taking, Innovativeness, and Proactivity Affect Business Performance of SMEs? A Case Study in Bangladesh. The Journal of Asian Finance, Economics and Business, 8(5), 689-695. https://doi.org/10.13106/JAFEB.2021.VOL8.NO5.0689

Singhdong, P., Suthi, K., \& PornchaiL, P. (2021). Factors Influencing Digital Transformation of Logistics Service Providers: A Case Study in Thailand. The Journal of Asian Finance, Economics and Business, 8(5), 241-251. https://doi.org/10.13106/JAFEB.2021.VOL8.NO5.0241

Suheny, E., Arum, M., Wandi, D., Rahmat, A., kurnianingsih, . A., Haerani, A., Dasmaran, V., Taryanto, , Adha, . S. \& Purwanto, A. (2020) Develop Leadership Style Model for Indonesian SMEs Leaders During Covid-19 Pandemic. Systematic Reviews in Pharmacy, 11(8), 576-586. doi:10.31838/srp.2020.8.82

Syafri, W., Prabowo, H., Nur, S. A., \& Muafi, M. (2021). The Impact of Workplace Green Behavior and Green Innovation on Green Performance of SMEs: A Case Study in Indonesia. The Journal of Asian Finance, Economics and Business, 8(5), 365-374. https://doi.org/10.13106/JAFEB.2021.VOL8.NO5.0365

Tan, J. D., Sugiarto, S., \& Budhijono, F. (2021). Family Business and Risk Management: Perspectives of SMEs Entrepreneurs in Indonesia. The Journal of Asian Finance, Economics and Business, 8(5), 851-861. https://doi.org/10.13106/JAFEB.2021.VOL8.NO5.0851

Tran, T. K. P., \& Truong, T. T. (2021). Impact of Servant Leadership on Public Service Motivation of Civil Servants: Empirical Evidence from Vietnam. The Journal of Asian Finance, Economics and Business, 8(4), 1057-1066. https://doi.org/10.13106/JAFEB.2021.VOL8.NO4.1057

Yunarsih, N., Rahayu, S., Fatoni, , Asra, ., Sustiyono, . A., Anwar, T., Sri, N. \& Purwanto, A. (2020) Develop Leadership Style Model for Nurse in Indonesian Hospital. Systematic Reviews in Pharmacy, 11(8), $352-361$. doi: $10.31838 /$ srp.2020.8.53

Wanasida, A. S., Bernarto, I., Sudibjo, N., \& Purwanto, A. (2021). The Role of Business Capabilities in Supporting Organization Agility and Performance During the COVID-19 Pandemic: An Empirical Study in Indonesia. The Journal of Asian Finance, Economics and Business, 8(5), 897-911. https://doi.org/10.13106/JAFEB.2021.VOL8.NO5.0897

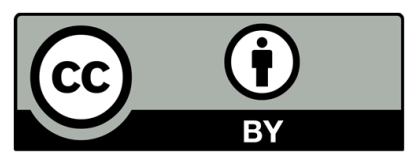

(C) 2021 by the authors; licensee Growing Science, Canada. This is an open access article distributed under the terms and conditions of the Creative Commons Attribution (CC-BY) license (http://creativecommons.org/licenses/by/4.0/). 